\author{
電気泳動法的手法による \\ 干潟底泥に存在するプロテアーゼの分析 \\ 中村 健一 \\ 県立広島大学生命環境学部環境科学科 \\ （７７34-8558＼cjkstart広島県広島市南区宇品東1-1-71）
}

[平成18年 9 月 8 日受理］

\title{
Development of an Electrophoretic Method to Analyze Proteases in Tideland Sediments
}

\author{
Ken-ichi NAKAMURA \\ Department of Environmental Sciences, Faculty of Life and Environmental Sciences, \\ Prefectural University of Hiroshima \\ (1-1-17 Ujinahigashi, Minami, Hiroshima, Hiroshima 734-8558)
}

[Received September 8, 2006]

\begin{abstract}
Summary
We present here an electrophoretic method to analyze proteases involved in tideland sediments based on a modified method reported by Heussen and Dowdle. The method revealed at least five proteases with different molecular masses in the tideland sediments from the Rokkaku River in Saga City. These proteases are selectively distributed in the soil fraction, but not in the tideland seawater. The electrophoretic analysis showed that there were marked differences in the protease patterns obtained from the sediments of various estuary tidelands; the Kamo River in Takehara City, the Enko River in Hiroshima City, and the Rokkaku River in Saga City. These results suggested that the proteases secreted from microorganisms into the tideland sediments are significantly influenced by the microorganism species and also environmental conditions that surround the tidal flats.

Moreover, we have found that the activities of the proteases revealed in an electrophoretic gel were quantitatively analyzed using image editing software.
\end{abstract}

Key words: Protease, Marine, Sediment, Electrophoresis, Enzyme

\section{1.はじめに}

海水浄化作用, 食物連鎖の基盤となる栄養塩類の産 生, 及び動植物の枯死や排泄物に由来する有機成分の分 解など, 数多くの代謝反応が干潟に打いて活発に営ま れ, 干潟内の生態環境が維持されている。これらの生態
環境の基盤形成に関わる基本的な代謝活性の多くは, 干 潟底泥に生息する細菌, 菌類, 原生生物, 線虫などのい わゆる微生物，あるいはそれら微生物から分泌された酵 素活性によって担われている ${ }^{1-3)}$ 。

微生物による代謝活性, とりわけタンパク質加水分解 活性は, デトリタス中, あるいは生物遺骸から放出され 
るタンパク質をペプチドやアミノ酸に分解する反応であ り, 干潟, 及び海洋生態系に果たす役割は極めて重要で あると考えられる。実際に, Keil らを始めとした多くの 研究者は, 海域や干潟に生息する従属栄養生物にとっ て, アミノ酸が主要な窒素栄養源であることを報告 ${ }^{46)} し$ ている。さらにBidle ら゙は, タンパク質を加水分解する 酵素, すなわちプロテアーゼに対する活性阻害剤の添加 が, 珪藻類の壊死から可溶化される珪素の循環過程を阻 害し, 海域の一次生産者である珪藻類の生育に悪影響を 与えることを報告した。さらに我々は，干潟底泥への夕 ンパク質の添加が, 微生物総量の指標となるATPバイオ マスの増加を伴わない状態で, リン酸塩の供給に深く関 わるフォスファターゼ活性の著しい活性増加（500～ 600\%）を引き起こすことを報告8するとともに，添加さ れたタンパク質が泥質プロテアーゼにより加水分解作用 を受け、ペプチドに分解されていることを明らかにした9。

以上の事実は，干潟底泥内に存在するプロテアーゼの 動態を探ることは，干潟，及び海域生態系に関与する物 質代謝の基礎的事象を理解するうえで重要であることを 明確に示している。しかしながら今まで，底泥を含めた 生態環境内のプロテアーゼに関わる研究は, 人工基質を 添加した総プロテアーゼ活性測定に限定され，個々のプ ロテアーゼの分布, 及び種類に関する研究例は皆無であ る。したがって，例えばある干潟底泥内に，何種類のプ ロテアーゼが存在して分解活性が担われているのか，あ るいは干潟底泥間のプロテアーゼが同一であるのかとい う基本的な問いには全く答えることができない。

我々はこれらの疑問に対して答えるべく, プロテアー ゼ分析法の開発について検討を進めてきた。その結果, 底泥中に複数のプロテアーゼが存在することを初めて検 出することに成功した。以下分析方法の紹介と併せ, 複 数の干潟泥質へ適用した結果についても報告する。

\section{2. 実験方法}

\section{1 干潟からの底泥採土と試料の調製}

有明海に臨む佐賀県佐賀市六角川河口干潟，広島県竹 原市賀茂川河口干潟, 及び広島市内の海田湾に開口する 猿侯川河口干潟を対象とし，それぞれ 6 月の大潮期の干 潟干出時に, 表層から $1 \sim 3 \mathrm{~cm}$ 間の部分の底泥を採取 した後, $1 \mathrm{~mm}$ のナイロンメッシュ篩を通過した土壤を 対象として以下のように試料を調製した。すなわち，分 析対象とした湿重量 $0.5 \mathrm{~g}$ の干潟底泥に, 電気泳動用試料 緩衝液 (0.125 M Tris-HCl, pH 6.5, 50 mM Dithiothreitol, 12\% Glycerol, $2 \%$ Sodium lauryl sulfate (SDS), 0. 0001\% Bromophenol blue）を $0.5 \mathrm{ml}$ 添加し, 遠心分離 用サンプルカップ内で充分に攪拌した後, $34 \mathrm{kHz}$ 超音波 処理 (Us-1, Asone Co., Osaka city, Japan) を10min 行っ
た。終了後ステンレスの針で攪拌・混合を繰り返した 後, 再び超音波処理を $10 \mathrm{~min}$ 行い, プロテアーゼを可溶 化した。な招超音波処理間は試料外部の漕内に砕片した 氷を加え, 温度が $20^{\circ} \mathrm{C}$ 以上に上昇しない上うにした。次 にサンプルカップを直接 $6,000 \times \mathrm{g}$ の遠心分離にかけ, 得 られた上澄み液をプロテアーゼの分析用試料として以下 の実験に用いた。

\section{2 プロテアーゼの電気泳動的分析}

土壤試料中のプロテアーゼを解析する目的で, 生化学 分野に扰いてタンパク質分離・分析の汎用手段となって いる Laemmli10) の SDS-ポリアクリルアミドゲル電気泳 動法 (SDS-PAGE) と Heusen と Dowdle のプロテアーゼ 再活性化法 ${ }^{11)}$ 組み合わせ，以下のように改変して分析 法を確立した。すなわちスラブ型電気泳動装置（Atto ラ ピタスミニスラブ $\mathrm{AE}-6500)$ 用の厚さ $1 \mathrm{~mm}$ のガラス平 板対 $(8 \times 9 \mathrm{~cm})$ 内に, 終濃度が $0.15 \%(\mathrm{w} / \mathrm{v})$ ゼラチ ン, $10 \%(\mathrm{w} / \mathrm{v})$ Acrylamide, $0.375 \mathrm{M}$ Tris $-\mathrm{HCl}(\mathrm{pH}$ 8.5)，6.3\% Glycerol，0.1\% SDSになるように混合し た電気泳動分離ゲルを作成した。分離ゲルが完全に重合 した後, Acrylamideの終濃度を3.25\%（w/v）とした濃 縮ゲルを作成した。次に, 泳動用緩衝液 (0.1\% SDS, 25 mM Tris, 0.19 M Glycine) を装置下部に満たした電 気泳動槽に、ゲルを含むガラス平板対を取り付けた。上 部にも同泳動用緩衝液を満たした後，ゲル上に作成した 試料溝に，底泥より前章の方法で調製した試料を通常 20 $\mu \ell$ 添加後, $20 \mathrm{~mA}$ の定電流で約 2 時間電気泳動を行っ た。

電気泳動後, プロテアーゼの再活性化は Heussen と Dowdleの方法 ${ }^{11}$ を参考にして, ゲルからタンパク質変性 剂SDSを取り除く目的で, 泳動後のゲルを0.5\%の TritonX-100で 2 回の液交換をしながら 2 時間振落した 後, プロテアーゼ再活性化溶液 (50 mM Glycine, pH8. 5）に浸して 1 時間振騰した。次に，液交換を行い $24^{\circ} \mathrm{C}$ 下で18時間静置した後, タンパク質染色液 (0. 0001\% Amido black, 30\% Ethanol, 7 \% Acetic acid) にゲルを浸して，ゼラチンの染色を 2 時間振騰しながら 行った後, 非特異的にゲルに吸着したAmid blackを脱色 液（30\% Ethanol，7％ Acetate）で取り除いた。プロテ アーゼの存在は, ゼラチン染色による青色のゲル中に, プロテアーゼが作用してゼラチンを分解・消失すること によって生じた青白色のバンドを検出することによって 行った。

試料中の底泥に含まれるタンパク質分析は，ゼラチン を含まないゲルを用いて同様にSDS-PAGE を行った後, 銀染色法（銀染色試薬第一, 生化学工業社) で染色を 行った。

最終的に得られたプロテアーゼパターンは，デイジタ 
ルカメラで撮影後, 画像ファイルをパソコンに取り达 み, ゲル画像解析ソフト (Gel-pro, Media Cybernetics 社）を用いて, 必要に応じ, 画像処理, プロテアーゼ活 性の定量的解析，及びプロテアーゼバンドの移動距離測 定を行った。

\section{3. 結果と考察}

\section{1 干潟底泥に存在するプロテアーゼの検出}

河川，及び海域から負荷された有機物に対する干潟微 生物の活発な加水分解反応, とりわけタンパク質分解活 性は, 海域や干潟生態系における物質循環を担う重要な 反応として Mayer ${ }^{12)}$ を始め, 多くの研究者により活性測 定がなされてきた。しかしながら測定は人工基質を用い た総プロテアーゼ活性測定に限定され，例えば干潟間の 底泥に存在するプロテアーゼの種類数, あるいは個々の プロテアーゼの活性分布比較など，プロテアーゼの種類 と干潟環境に関する重要な情報についてはほとんど得ら れていない現状である。これは, 底泥内に存在する個々 のプロテアーゼの分離・分析手法が確立されていないこ とに起因している。

本研究は, 体組織, 体液中のプロテアーゼの分離・検 出に用いられている Heussen と Dowdle の方法 ${ }^{11}$ を応用 し, 干潟底泥中のプロテアーゼ分析法を確立することを 目的としてなされた。方法においては，ゲルに添加する ゼラチン濃度を原法の $0.1 \%$ から $0.15 \%$ に増加し, ゲル 中のプロテアーゼ活性による消化された部分と非消化部 分の対比を明確にした。さらにGlycine を含む再活性化 溶液の温度を従来の $37^{\circ} \mathrm{C}$ に変え, 自然環境で発現する底 泥プロテアーゼを考慮して $24^{\circ} \mathrm{C}$ に設定する一方，原法の $3 \sim 5$ 時間の反応時間を18時間とし，プロテアーゼによ りゲル中のタンパク質の一種であるゼラチンの消化が十 分に施された後に検出を行うことにした。

さらに分析においては特に, 底泥から効果的にプロテ アーゼを抽出する方法についての検討が重要な課題で あった。この問題解決には, タンパク質の一種であるア ルブミンを干潟底泥に添加した場合, 表面活性剂の一種 であるSDS存在下での超音波処理により, 泥質粒子に吸 着したアルブミンがほぼ100\%可溶化されるという先行 研究の結果 ${ }^{9}$ が有効な情報となった。その結果を踏まえ, 高濃度のSDS を含むタンパク質処理液を土壤に添加し, 十分な時間の超音波処理を行って土壤からのプロテアー ゼを可溶化した後, 遠心分離を行い, 得られた上澄み液 を分析試料とした。

Fig. 1のレーンPは，以上の検討を踏まえたプロテ アーゼ分析法を, 実際に佐賀市六角川河口泥質試料に適 用して得られたプロテアーゼパターンである。一様に濃 い青色に染色されたゼラチンを含むゲル上に，実線の矢
印で示した 4 種類の明確な青白色を呈するバンドと，点 線の矢印で示したわずかに白いバンドが存在することが 明らかになった。この青白色バンドが生ずる理由は,

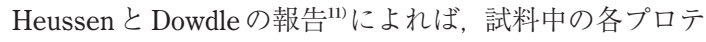
アーゼがSDS-PAGEの原理により，分子量にしたがっ て移動度が異なる位置に分離された後, 再活性化処理に よってプロテアーゼ活性能を回復し，プロテアーゼに接 触しているゲル中のゼラチンを消化することに基づいて いる。その結果, ゼラチン染色操作に対して消化された ゼラチン部分は反応せずし, 青白色を呈することにな り, プロテアーゼの位置が同定できる。以上のことか ら, 対象とした六角川河口干潟底泥には, 移動度の少な い位置に一種類（T)，そして移動度中位部分に矢印で示 した 4 種類, 併せて少なくとも 5 種類の分子量の異なる プロテアーゼが存在することが明らかになった。原理か ら予想されることではあるが, 本検出法はプロテアーゼ の分離としてタンパク質変性剂であるSDS 存在下での 電気泳動を行っているため, 同定されたプロテアーゼ は, 変性後の再活性処理で活性を回復したプロテアーゼ に限定される。したがって，本研究で明らかになったプ ロテアーゼ以外にも, プロテアーゼが干潟底泥には存在 する可能性が残されている。

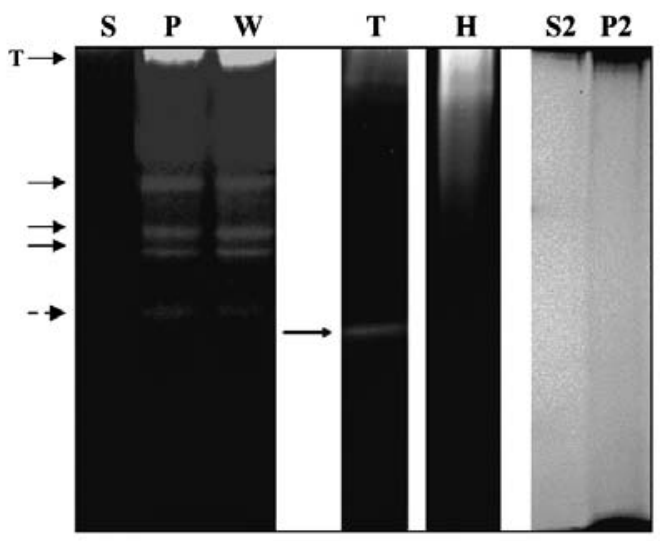

Fig. 1 Detection of proteases and staining of proteins in sediments from estuary tidelands

Sediment samples of the lanes (P, W, S2 and P2) were from the Rokkaku River in Saga City of the Saga prefecture. Those of lanes T and $\mathrm{H}$ were from the estuary tidelands of the Kamo River in Takehara City, and from the Enko River in Hiroshima City, respectively. Lane $\mathrm{S}$ indicates the protease detection of seawater from the tideland of the Kamo River. Protease detection (S, P, W, T, H). Protein staining (S2, P2) 
干潟間隙水 (S2) 及び底泥（P2）試料中に存在する夕 ンパク質を，ゼラチンを含まない通常の Laemmli 法(10)に よるSDS-PAGEで分離し, タンパク質の高感度検出法 として用いられている銀染色法で分析した（レーン S2, P2）。しかしながら泥質土壤分画（レーンP2）の高分子 量領域には，矢印（T）で示されたプロテアーゼに相当 する位置に，黒く染色されたタンパク質の存在が示され てはいるものの, 移動度中間部分の括弧で括られた 4 種 類のプロテアーゼ活性バンドに相当する位置には, 明確 なタンパク質の存在を検出することはできなかった。こ の事実から, 銀染色検出限界以下（通常数10ng >) の極 微量のプロテアーゼタンパク質が, 高いプロテアーゼ活 性をゲル上に示していることが明らかになった。

\section{2 プロテアーゼの干潟底泥内分布}

Fig. 1 レーン S は，干潟底泥を含む海水を遠心分離す ることによって得られた上澄み液の分画，すなわち海水 分画に等量の電気泳動用試料緩衝液を加え，含まれるプ ロテアーゼを同様の方法で解析した結果である。白いバ ンドの出現は全く見られず，干潟底泥に扔けるタンパク 質分解活性は，海水部分にはほとんど存在しないことが 明らかになった。一方, レーン $\mathrm{W}$ は，干潟底泥を遠心分 離して得られた沈殿を人工海水で懸濁し，再び遠心分離 操作を 3 度行って得た底泥土壤のプロテアーゼを分析し た結果である。その結果，無処理の干潟底泥を対象とし たレーン P とほぼ同様の位置に同程度の青白色バンドが 検出され，干潟底泥に存在するプロテアーゼは，洗浄後 も土壤分画に存在していることが明らかになった。土壤 酵素の多くが, 微生物から体外に分泌され，腐葉土·酵 素複合体を形成して存在する ${ }^{13.14)}$ という知見と併せて考 察すると，この結果から，干潟微生物によって体外に分 泌されたプロテアーゼは，干潟の砂土もしくは泥粒子に 固く結合していることが示唆された。

\section{3 プロテアーゼパターンの干潟間比較}

次に，干潟に扔けるプロテアーゼの役割や干潟の環境 状態とプロテアーゼの関係を明らかにする目的で，六角 川河口干潟底泥に検出されたプロテアーゼパターンが, 環境条件の異なる他干潟とはどの程度異なるかについて 検討を行った。そこで, 広島県竹原市賀茂川河口干潟, 及び広島市内の海田湾に開口する猿侯川河口干潟の底泥 についても，同様のプロテアーゼ分析を行った。その結 果，賀茂川河口干潟（Fig. 1 レーンT）に打いては，移 動度の大きい位置を含め, 少なくても2 種類のプロテ アーゼ活性バンドの存在が見いだされ，六角川河口干潟 とは分子量において明確に異なるプロテアーゼが存在す ることが明らかになった。さらに興味あることに，猿侯 川河口干潟底泥（レーンH）の場合は他二カ所とは全く
異なり，移動度の低い分子量の大きな領域に高いプロテ アーゼ活性の存在が認められるものの, プロテアーゼバ ンドはスメアーな状態であり, 特定の鮮明なバンドの存 在を見いだすことができなかった。この結果は，多種類 のプロテアーゼ同士が活性を保ちつつ，相互に消化と会 合を示して多型体として存在していることを示唆してい る。

対象とした 3 干潟の中で，六角川河口と賀茂川河口の 干潟は甲殼類をはじめ生物層が多様であり, 吉田の分類 基準 ${ }^{15)}$ ，及び我々の提唱した ATP バイオマス值とフォス ファターゼ活性測定による干潟環境類型化指数による判 定(6)では豊栄養海域に属する干潟として分類されたのに 対し，猿侯川河口干潟は，マクロベントスの生息を見い だすことができなかった。さらに，この猿侯川河口干潟 は，ATPバイオマス值とフォスファターゼ活性測定予備 実験の結果，底泥の総窒素，総リン酸，さらには強熱減 量測定による有機物含有量が著しく高く，腐栄養海域に 属する干潟と判定 ${ }^{16}$ され，他の二カ所の干潟とは著しく 異なる環境であった。したがって猿侯川河口で観察され たゲル上部のスメアーなプロテアーゼ活性バンドは，污 染された干潟の特性とも推定され，プロテアーゼパ夕ー ン解析が, 環境污染の新たな指標となる可能性を示して いる。さらに, 三力所の干潟底泥のプロテアーゼパター ンの違いは, 上記の環境類型の差違と併せ，地理的違い による生息微生物種の違いや，底泥がおかれた生態環境 を微妙に反映していると思われる。実際に，同じ河口干 潟に扔いても，河川が流入し常時冠水している箇所と, 干潮時に干出する箇所では, 本法で分析された底泥プロ テアーゼパターンに拉いて明らかに異なる結果が得られ ている (未発表)。現在, さらに多くの干潟を対象とし, 底泥のプロテアーゼパターンの特性と干潟の生態的環境 との関連性について検討を進めている。

\section{4 プロテアーゼパターンの定量的解析}

本研究により干潟底泥に存在するプロテアーゼを，電 気泳動的手法により青色に染色されたゲル上に，青白色 のバンドとして視覚的にとらえることに成功した。この 場合，プロテアーゼ活性が高い場合は，基質であるゼラ チンの消化がすみやかに進行することから，白色がより 明確になると推定される。したがって, 白色の程度から 定量的にプロテアーゼの活性を比較検討できる可能性が 期待できる。そこで次に，青白色の濃淡とプロテアーゼ 活性量との間にどの程度の相関があるのかについて検討 を行った。Fig. $2 \mathrm{~A}$ は, 六角川河口干潟底泥から SDS を 含む泳動用タンパク質処理溶液に可溶化された上澄み液

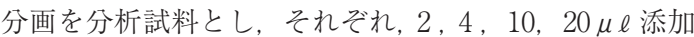
し，前述のプロテアーゼの電気泳動的分析を行った結果 である。Fig. 1 で明らかになった点線矩形内の 3 種類の 
プロテアーゼを対象とし，相当する部分を拡大した。添 加量の増加に対応して白色部分が濃くなることが，それ ぞれのプロテアーゼバンドについて定性的に認められ た。そこで次に，定量的な比較が可能かどうかを検討す る目的でゲル画像解析ソフトを用い, Fig. $2 \mathrm{~A}$ の白黒反 転を行った後（Fig. 2 B)， バックグランドの平坦化処理 を行い, 各レーンの濃淡を, グラフ表示した (Fig. 2 C)。 それぞれバンドに相当する部分がピークとして表示さ れ，ピーク長を測定することで活性の程度が相対的に比 較できる。Fig. $2 \mathrm{D}$ に，試料の添加量とピーク長の関倸 をグラフにプロットするとともに，回帰式とその相関係 数を示した。各プロットはほぼ直線上に回帰され，その 相関係数 $\mathrm{r}$ は, 対象とした $\mathrm{a}, \mathrm{b}, \mathrm{c}$ のプロテアーゼに対し てそれぞれ0.998，0.982，0.988となった。この結果，電 気泳動法と画像解析ソフトを用い, 泳動パターンを通し
て得られた各プロテアーゼの活性を定量的に比較検討で きることがわかった。

\section{4. まとめ}

本研究により各干潟底泥中には，土砂，あるいはシル 卜に固く結合した，分子量の異なるプロテアーゼが複数 存在することが明らかになった。一般にプロテアーゼ は，反応機構上，セリンプロテアーゼ，チオールプロテ アーゼ，あるいは金属プロテアーゼなどに分類されてい ることが知られている。本研究で明らかにした複数のプ ロテアーゼについて，各種プロテアーゼ阻害剤などを用 いた研究により反応機構上の分類を進め, これら干潟底 泥プロテアーゼの特性と環境との関わりをさらに明らか にしてきたいと考えている。なおこのプロテアーゼ分析
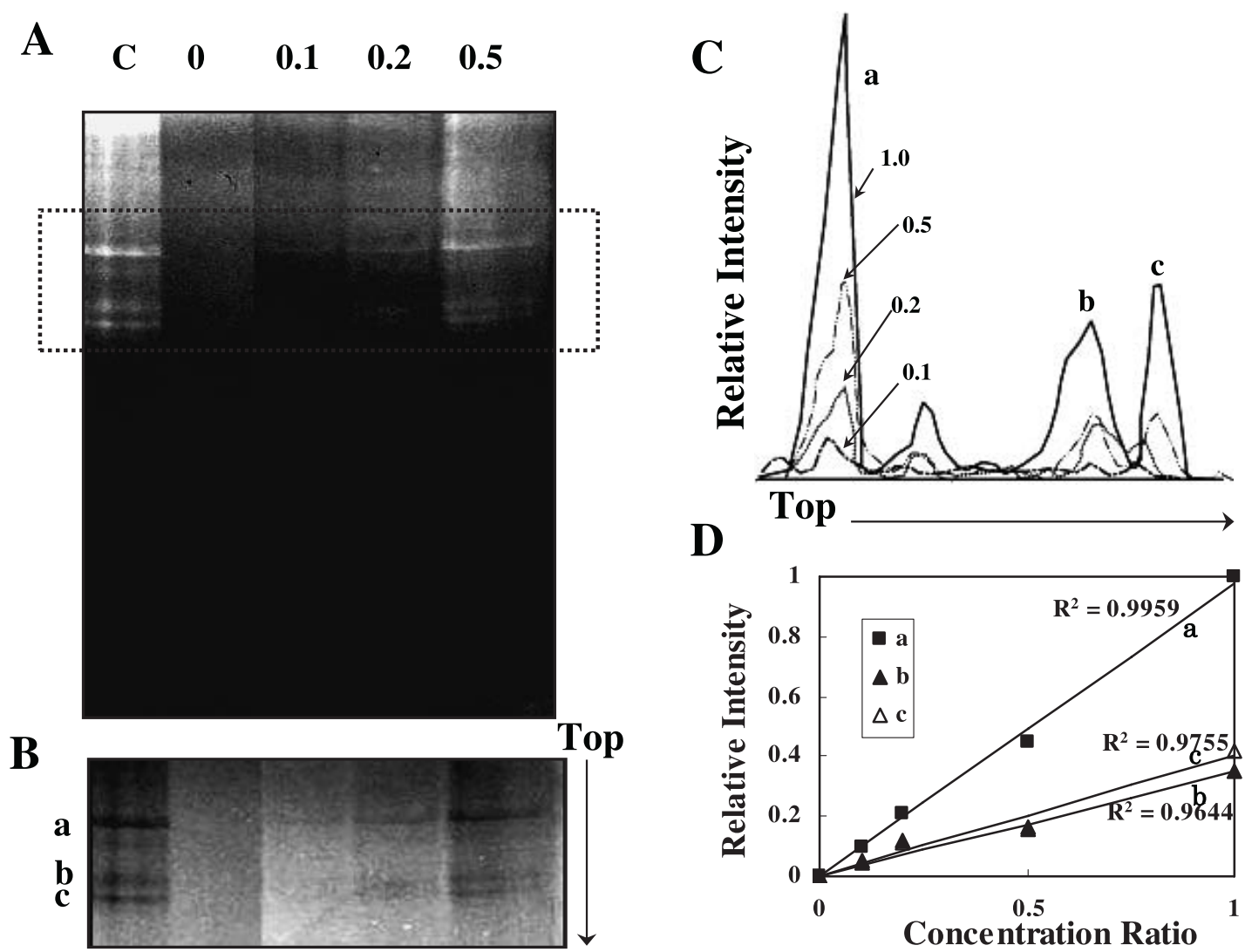

Fig. 2 Quantitative analysis of protease bands revealed on a gel using the present method

(A) Active bands with protease activities detected by the present method. The number on each lane indicates the ratio of the sample volume applied on the gel $(20 \mu \ell=1$, lane $\mathrm{C})$.

(B) Monochrome reversing image of the dotted area in Fig. $2 \mathrm{~A}$.

(C) Densitometric analysis of each band with protease activity in Fig. 2 B.

(D) Graphical plot of the relation between each peak height and the amount of sample used for the assay. 
方法はタンパク質変性剤であるSDS 存在下で電気泳動 を行っているため, 同定されたプロテアーゼは, 変性後 の再活性処理で活性回復可能なプロテアーゼ種の同定 . 検出に限定される。併せて示された活性の程度は，必ず しも自然環境に扔ける活性をそのまま反映してはいない ことについても留意する必要がある。しかしながら、ぺ プシン, ブロメライン, トリプシン, プラスミン, アク チニジンを始め, 我々が試みた範囲では多くのプロテ アーゼが本法で検出・活性を示すことが明らかにされて いる (未発表)。また実際に複数のプロテアーゼが土壤 で検出されることに併せ，画像ソフトの活用により，同 一バンドで示されるプロテアーゼ種の間では，相互に活 性の定量的な比較検討が可能であることが示された。以 上のことからこの電気泳動的手法によるプロテアーゼ分 析法は，今後，干潟に扔ける物質循環や食物連鎖の基盤 形成に重要な役割を持つとされている底泥のプロテアー ゼと環境との関係を検討する上での有用な手段になると 思われる。

近年，環境変異に対する土壤微生物種の集団的変化を 探る手段として, PCR 法と電気泳動的 DNA 分析法を組 み合わせた DGGE 法 ${ }^{17,18}$ (変性剂濃度勾配ゲル電気泳動 法）が幅広く用いられている。しかしながら DGGE 法 は，対象となる土壤中の遺伝集団の変化を知る手段とし ては有効であるものの，環境変化に応じてどのような酵 素が生態系内で実際に発現され，代謝活性変動を遂げて いるのかについて具体的な情報は全く得ることはできな い。したがって，本研究によって明らかにしたような干 潟環境を担う特定の酵素の種類と活性量を活性パターン として電気泳動的に表示できるいわゆる“土䁃ザイモグ ラフ法”とでも称すべき手法と従来の DGGE 法と組み合 わせて研究することは，微生物の環境的変位の量的，質 的変化の解析にとって極めて有用であると思われる。両 方法の連携は，干潟のみならず土壤も含めた微生物にお ける生態系の環境変異を探る研究に対して大きな貢献を することが期待される。

今後は存在の明らかになったプロテアーゼの Native な状態での存在様式の解明と併せてフォスファターゼや ウレアーゼなど生態循環系の基盤形成を担う主要な微生 物分泌酵素の土壤ザイモグラフの開発を進め, 干潟の環 境変化と干潟の微生物代謝の活性変動との連関の解明に も応用していきたいと考えている。

\section{謝 辞}

本研究は, 平成16 18年度学術振興会科学研究費基盤 （C）及び平成16年度（財）河川管理財団からの河川整備 基金助成事業研究費助成（16-1-4-27）によってなされ た。

\section{要 約}

電気泳動法的手法を用い，干潟底泥に含まれるプロテ アーゼをゼラチンゲル上に分離・分析する方法を確立し た。その結果，佐賀県佐賀市六角川河口干潟土壤に分子 量の異なる少なくとも 5 種類のプロテアーゼの存在を明 らかにすることができた。また竹原市賀茂川河口干潟, 及び広島市猿侯川河口干潟の底泥についても分析した結 果, 3 力所の干潟底泥はそれぞれ異なるプロテアーゼパ ターンを示すことがわかった。さらに，底泥を海水と土 壤部分に分離して分析した結果，プロテアーゼは総て土 壤分画に存在することが明らかになった。

次に，本分析法で，分離・分析された各プロテアーゼ の活性を定量的に検討する可能性を検討した。その結 果，電気泳動用画像処理ソフトを用いることにより，プ ロテアーゼパターンとしてゲル上に分析された個々のプ ロテアーゼ活性を，定量的に比較検討できることが明ら かになった。

\section{文 献}

1）栗原 康：干潟は鬿るか，pp139-199，「干潟は生き ている」, 岩波新書（1980）

2) Meyer-Reil, L.-A.: Seasonal and spatial distribution of extracellular enzymatic activities and microbial incorporation of dissolved organic substrates in marine sediments. Apply. Environ. Microbiol., 53, 1748-1755 (1987)

3）大和田紘一：総論：海洋微生物研究の現状と展望, 月刊海洋， 23，5-9 (2000)

4) Palenik, B. and Morel, F.M.M.: Amino acid utilization by marine phytoplankton: A novel mechanism. Limnol. Oceanogr., 35, 260-269 (1990)

5) Keil, R.G.: Dissolved combined amino acids: Chemical form and utilization by marine bacteria. Limnol. Oceanogr., 38, 1256-1270 (1993)

6) Dauwe, B., Middelburg, J.J., Van Rijswijk, P., Sinke, J., Herman, P.M.J. and Heip, C.H.R.: Enzymatically hydrolyzable amino acids in North Sea sediments and their possible implication for sediment nutritional values. J. Marine Res., 57, 109134 (1999)

7) Bidle, K.D., Brzezinski, M.A., Long, R.A., Jones, J.L. and Azam, F.: Diminished efficiency in the oceanic silica pump caused by bacterially-mediated silica dissolution. Limnol. Oceanogr., 48, 1855-1868 (2003)

8）中村健一, 高谷知恵子, 斎藤 博, 網谷貴彰, 睦田 秀実：土壤フォスファターゼ活性值と ATP バイオ 
マス值に基づく干潟土壤環境類型化式の応用, 土木 学会論文集，VII-28，23-28（2003）

9) Nakamura, K.-I.: Analysis of protease digestion patterns in tideland sediments using SDS-PAGE. $J$. Exp. Marine Biol. Ecol. 2006 (in press)

10) Laemmli, U.K.: Cleavage of structural proteins during the assembly of the head of bacteriophage T4. Nature 227, 680-685 (1970)

11) Heussen, C. and Dowdle, E.B.: Electrophoretic analysis of plasminogen activators in polyacrylamide gels containing sodium dodecyl sulfate and copolymerized substrates. Anal. Biochem. 102, 196202 (1980)

12) Mayer, L.M.: Extracellular proteolytic enzyme activity in sediments of an intertidal mudflat. Limnol. Oceanogr. 34, 973-981 (1989)

13) Ruggiero, P. and Radogna, V.M.: Properties of laccase in humus-enzyme complexes. Soil science, 138, 74-87 (1984)

14) Pascual, J.A., Moreno, J.L., Hernández, T. and García, C.: Persistence of immobilised and total urease and phosphatase activities in a soil amended with organic wastes. Biores. Technol. 82, 73-78 (2002)

15）吉田陽一：低次生産段階における生物生産の変化, pp92-104, 「水圈の富栄養化と水産増養殖」, 水産生 物学会編 恒星社厚生閣（1973）

16) Nakamura, K.-I. and Takaya, C.: Assay of phosphatase activity and ATP biomass in tideland sediments and classification of the intertidal area using chemical values. Marine Pollution Bulletin, 47, 1017 (2002)

17) Gelsomino, A., Keijzer-Wolters, A.C., Cacco, G. and van Elsas, J.D.: Assessment of bacterial community structure in soil by polymerase chain reaction and denaturing gradient gel electrophoresis. $J$. microbial. Methods 38, 1-15 (1999)

18) Maarit Niemi, R,, Heiskanen, I., Wallenius, K. and Lindstrom, K.: Extraction and purification of DNA in rhizosphere soil samples for PCR-DGGE analysis of bacterial consortia. J. Microbiol. Methods 45, 155-165 (2001) 